\title{
Pelatihan Standar Akuntansi Pesantren dalam penyusunan laporan keuangan bagi staf keuangan pondok pesantren
}

\author{
Yuliansyah $^{1}$, Fajar Gustiawaty Dewi ${ }^{2}$, Yunia Amelia ${ }^{3}$. \\ Universitas Lampung ${ }^{1,2,3}$ \\ yuliansyah@feb.unila.ac.id ${ }^{l}$,fajar.Gustiawaty@feb.unila.ac.id ${ }^{2}$.yunia.amelia@feb.unila.ac.id ${ }^{3}$
}

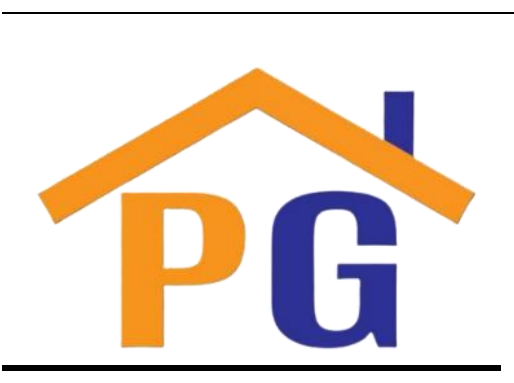

Riwayat Artikel

Diterima pada 07 Agustus 2020

Revisi 1 pada 21 Agustus 2020

Revisi 2 pada 27 Agustus 2020

Revisi 3 pada 29 Agustus 2020

Disetujui pada 31 Agustus 2020

\begin{abstract}
Abstrak:
Kegiatan pengabdian ini bertujuan untuk membantu pesantren agar dapat lebih baik dalam menyusun laporan keuangannya agar akuntabilitas dan tanggung jawab dari laporan keuangan dapat dipertanggungjawabkan ke publik secara lebih baik pesantren untuk penyusunan laporan keuangan berdasarkan standar akuntansi pesantren. Lokasi mitra pengabdian berada di Way Ratai Kabupaten Pesawaran dan di Dusun Umbul Kates Tanjung Sari Natar, dimana terdapat pondok pesantren penghafal alquran dan Pondok Pesantren Al Hidayah. Metode yang digunakan pelatihan, pendampingan dan pendampingan penerapan Teknologi dengan Luaran dari hasil pengabdian ini adalah meningkatnya pengetahuan dan keahlian staf keuangan mitra dalam penyusunan laporan keuangan berdasarkan standar yang sudah ditetapkan oleh organisasi profesi Ikatan Akuntan Publik dan dapat dipublikasikan pada jurnal atau prosiding pengabdian pada masyarakat serta diberitakan dalam media online. Hasil pengabdian yang dilaksanakan secara keseluruhan, kenaikan pengetahuan dan pemahaman peserta pelatihan rata-rata 30 persen dari keseluruhan peserta. Sedangkan kenaikan sebesar 0 persen dialami oleh 5 peserta yang tetap belum memahami mengenai materi yang disampaikan dan merasa kurang cukup waktunya, membutuhkan penjelasan secara lebih intens. 100 persen peserta kegiatan rata-rata belum pernah mengikuti pelatihan sejenis, sehingga dibutuhkan pendampingan lebih lanjut.

Kata kunci: Pelatihan, Pedoman Akuntansi Pesantren
\end{abstract}

\section{PENDAHULUAN}

Saat ini pondok pesantren telah menjadi lembaga pendidikan dengan sistem pendidikan yang semakin diminati oleh masyarakat di Indonesia. Data yang diperoleh dari pengelola pondok pesantren kementerian agama saat ini jumlah pondok pesantren di Indonesia mencapai 26.000 lembaga dengan total santri mencapai 4 juta jiwa. Dalam pencatatan keuangannya pondok pesantren banyak yang masih menggunakan metode pencatatan manual atau sederhana. Hanya sedikit sekali pesantren yang melakukan pencatatan dan pelaporan keuangan yang sesuai dengan standar akuntansi yang umumnya berlaku. Pesantren merupakan organisasi yang tidak berorientasi pada laba namun penting adanya laporan keuangan yang baik dan benar. Perkembangan peraturan, standar yang semakin lengkap, dan kompleks pada pondok pesantren (Afkarina, 2019). Terciptanya pemberdayaan pesantren yang baik ditandai dengan adanya laporan keuangan yang akuntabilitas dan sesuai standar. Standar yang dipakai adalah Pedoman Akuntansi Pesantren yang merupakan standar yang disusun Oleh Ikatan Akuntan Indonesia bekerjasama dengan Kompartemen Bank Indonesia (Lulita, 2019). Pedoman ini sudah sesuai dengan SAK ETAP DAN PSAK 45 dalam penyusunan Laporan keuanganny (Sulistiani, 2020).

Permasalahan di Pondok Pesantren. Pertama, pengelola pesantren yang belum memahami bahkan mengetahui adanya standar yang mengatur keuangan pesantren yang disebabkan belum adanya sentuhan langsung dari pemerintah perihal pelatihan dan pendampingan penyusunan laporan keuangan. Kedua, sarana dan prasarana yang dimiliki pesantren masih sangatlah minim, seperti komputer dan alat 
tekhnologi lainnya. Hal tersebut disebabkan oleh rendahnya sumber daya manusia (SDM) yang ada dalam mengimplementasikan pedoman akuntansi pesantren (Alfani, 2016). Hal ini diidentifikasi tim pengabdian juga merupakan hambatan yang dialami mitra pengabdian yaitu staf keuangan dan pengelola pondok pesantren. Pelaporan keuangan berdasarkan Pedoman Akuntansi Pesantren belum dilakukan dikedua sasaran yang dijadikan mitra dalam pengabdian ini. Pencatatan keuangan dilakukan secara sederhana dan manual, hanya berupa pencatatan penerimaan dan pengeluaran kas, sedangkan pondok pesantren selain mengelola dana yang berasal dari santri juga mengelola dana yang diperoleh dari bantuan berbagai sumber lain. Pondok pesantren merupakan salah satu lembaga pendidikan organisasi nirlaba keagamaan non pemerintah yang mengedepankan suatu pelayanan pada pihak eksternal (Niati, Suhardjo,Wijayanti, 2019), karenanya menjadi sangat dibutuhkan pelaporan keuangan yang lebih terstandar, akuntabel dan dapat dipertanggungjawabkan.

Pentingnya akuntansi sebagai sistem pencatatan keuangan sekaligus sebagai alat pertanggungjawaban keuangan bagi stakeholder terkait, tidak terelakkan termasuk untuk lembaga nirlaba khususnya pondok pesantren yang memiliki ciri khas tersendiri, beberapa fenomena yang ditemukan peneliti di lapangan adalah transaksi yang terjadi di pesantren modern saat ini bisa disebut transaksi yang cukup besar (Suherman, 2019), karena itu staf keuangan pondok pesantren perlu menyusun laporan keuangan berdasarkan standar akuntansi keuangan pondok pesantren yang bertujuan untuk mengimplementasikan pedoman tersebut kedalam kondisi riil pondok pesantren. Pedoman bagi pondok pesantren ini hanya berlaku untuk pondok pesantren berbentuk yayasan untuk menjaga akuntabilitas laporannya.

Hasil penelitian banyak ditemukan pondok pesantren dalam menyusun laporan keuangannya belum sesuai dengan Pedoman Akuntansi Pesantren, hanya sebatas membuat laporan pemasuka dan pengeluaran kas saja (Auliavirda, 2019). Pondok Pesantren sudah menyusun laporan keuangan, akan tetapi masih belum sesuai dengan Pedoman Akuntansi Pesantren dikarenakan yang sajikan dalam laporan keuangan pondok pesantren hanya sebatas aktivitas kas masuk dan kas keluar saja (Huda, 2019). Ikatan Akuntan Indonesia sudah menyusun pedoman akuntansi pesantren yang diluncurkan pada Mei 2018. Di Tahun 2019 berada di tahapan sosialisasi didalam penggunaanya, karena itu di Tahun 2020 pedoman ini menjadi sangat relevan untuk disosialisasikan secara masif dan terstruktur bagi pondok pondok pesantren. Terdapat Kendala yang dialami oleh Pondok Pesantren dalam penerapan Pedoman Akuntansi Pesantren dikarenakan minimnya informasi dan sosialisasi tentang pelaporan keuangan khususnya Pedoman Akuntansi Pesantren yang mereka dapat (Firmansyah, 2019). Hal itulah yang motivasi dari tim pengabdian untuk dapat memberikan pelatihan mengenai pedoman akuntansi tersebut.

Secara umum, kedua mitra pondok pesantren menghadapi permasalahan dalam penyusunan laporan keuangan yang hampir serupa, yaitu:

1. Masih minimnya pengetahuan staf keuangan pondok pesantren mengenai pedoman akuntansi pesantren.

2. Minimnya literatur mengenai bagaimana menyusun laporan keuangan bagi pondok pesantren.

3. Masih minimnya wawasan dan pengetahuan mitra dalam menganalisa laporan keuangan pondok pesantren.

4. Minimnya pengetahuan tentang bagaimana meningkatkan value laporan keuangan pondok pesantren bagi peningkatan kesejahteraan pondok.

Tujuan kegiatan pengabdian kepada masyarakat ini adalah:

1. Meningkatkan pengetahuan dan pemahaman staf keuangan pondok pesantren mengenai pedoman akuntansi pesantren.

2. Menambah kuantitas dan kualitas literatur mengenai bagaimana menyusun laporan keuangan bagi pondok pesantren.

3. Meningkatkan wawasan dan pengetahuan mitra dalam menganalisa laporan keuangan pondok pesantren.

4. Meningkatkan pengetahuan tentang bagaimana meningkatkan value laporan keuangan pondok pesantren bagi peningkatan kesejahteraan pondok. 
Setelah kegiatan pengabdian ini selesai dilaksanakan, maka manfaat bagi mitra pengabdian adalah dapat menyusun laporan keuangan sesuai dengan standar akuntansi pesantren, dengan bantuan teknologi yang mudah digunakan, sehingga semua stakeholder dari pondok pesantren dapat informasi yang akuntabel dan bermanfaat, juga dapat menjadi role model bagi pondok-pondok pesantren lainnya dalam menyusun laporan keuangan.

\section{METODE}

Kegiatan pelatihan, pendampingan dan pengimplementasian dilaksanakan dalam dua tahap, pada minggu ke-2 dan ke-3 Agustus 2020, bertempat di pondok pesantren dengan narasumber tim Dosen pengabdian dari Fakultas Ekonomi dan Bisnis Jurusan Akuntansi Universitas Lampung. Adapun materi yang akan disampaikan adalah: Pedoman Akuntansi pesantren, implementasi penyusunan laporan Keuangan Pesantren, analisa laporan keuangan pesantren. Metode yang digunakan adalah Pelatihan, pendampingan dalam penerapan teknologi.

Prosedur kerja untuk mendukung realisasi penerapan ipteks/metode yang ditawarkan melalui tahapan langkah-langkah yang ditempuh guna melaksanakan solusi atas permasalahan spesifik yang dihadapi oleh mitra dapat dijabarkan sebagai berikut:

1. Penyiapan materi, alat dan peralatan pendukung media pelatihan dan pendampingan.

2. Penjadualan waktu dan pelaksanaan pelatihan dan pendampingan.

3. Pelaksanaan kegiatan pelatihan dan pendampingan.

4. Evaluasi kegiatan pelatihan dan pendampingan.

5. Pembuatan laporan, seminar, publikasi.

Pihak-pihak yang terlihat dalam dalam kegiatan tersebut; Mitra pengabdian staf keuangan dan pengelola pondok pesantren yang sudah menyatakan kesediannya menjadi mitra pengabdian; Organisasi Profesi Ikatan Akuntan Indonesia untuk literasi pedoman akuntansi pesantren; Mahasiswa untuk membantu dalam proses penyiapan untuk pelaksanaan pelatihan; Dosen tim pengabdian dari Jurusan Akuntansi untuk menjadi pemateri; Alumni untuk membantu tim pengabdian memberikan pendampingan lanjutan.

Mitra bersedia bekerjasama dengan mengikuti pelatihan yang akan diberikan oleh tim pengabdian dan melaksanakan hasil rekomendasi dari tim pengabdian untuk dapat mengatasi masalah minimnya pengetahuan sdm staf keuangan dalam penyusunan laporan keuangan mengunnakan standar akuntansi pesantren yang telah disusun oleh organisasi profesi akuntansi Ikatan Akuntan Indonesia.

Dengan adanya kegiatan pengabdian ini masalah masih minimnya pengetahuan staf keuangan pondok pesantren mengenai akuntansi pesantren disebabkan tidak adanya literatur dan belum dapat menerapan teknologi aplikasi mengenai bagaimana menyusun laporan keuangan bagi pondok pesantren, rendahnya wawasan dan pengetahuan mitra dalam menganalisa laporan keuangan pondok pesantren dan rendahnya value laporan keuangan pondok pesantren bagi peningkatan kesejahteraan pondok dapat ditingkatkan. Keberlanjutan program dapat dilakukan melalui pendampingan secara rutin untuk melihat apakah materi yang disampaikan dapat diimplementasikan dengan baik oleh mitra.

\section{HASIL DAN PEMBAHASAN}

Tahapan mengenali pondok pesantren dari sisi bentuk hukum dan struktur organisasi menjadi titik awal dalam masa pelatihan. Tahapan ini untuk menentukan apakah pondok pesantren sebagai suatu entitas pelaporan(Susetyo, Atikah, \& Fitriyah, 2020). Kegiatan pengabdian kepada masyarakat ini dilaksanakan melalui tahapan-tahapan sebagai berikut:

1. Rapat perencanan kegiatan yang dihadiri oleh seluruh anggota tim pengabdian.

2. Tahap selanjutnya, masing-masing anggota tim mempersiapkan materi sesuai dengan bidangnya masing-masing.

3. Melakukan kontak awal dan berkomunikasi dengan Pimpinan Pondok Pesantren untuk mempersiapkan pelaksanaan kegiatan, akhirnya disepakati pelaksanaan kegiatan pengabdian di Lokasi Pesantren dengan peserta santri, pengurus dan pengelola Pondok Pesantren.

4. Berkoordinasi dengan Pimpinan Pondok Pesantren untuk menggunakan aula, masjid dan lapangan pondok pesantren menjadi tempat pelaksaan kegiatan. 
5. Mengirimkan surat ke seorang narasumber ahli tanaman untuk menjadi salah satu narasumber kegiatan terkait edukasi kegiatan penanaman pohon.

6. Pelaksanaan kegiatan pelatihan dan pendampingan.

7. Penyusunan Laporan, pembuatan artikel publikasi.

Kegiatan pengabdian ini dilaksanakan pada dua lokasi pengabdian pada Hari Sabtu Tanggal, 8 Agustus 2020 bertempat di Pondok Pesantren Al Hidayah di Way Ratai Pesawaran dengan jumlah Peserta 30 Peserta Santri dan 4 Pengurus Ustad Pondok. Palaksanaan di Mitra kedua pada hari Hari Sabtu, Tanggal 15 Agustus 2020, bertempat di Pondok Pesantren Darul Iman Tahfidzul Quran Boarding school di Desa Tanjung Sari Kecamatan Natar Lampung Selatan dengan jumlah peserta sebanyak 30 Peserta. Personalia pengusul kegiatan pengabdian ini merupakan dosen dari akuntansi yang mengampu mata kuliah akuntansi biaya, akuntansi manajemen dan akuntansi keuangan, sehingga dapat memberikan pelatihan kepada mitra terkait bagaimana akuntansi pencatatan untuk pesantren. Materi yang diberikan:

1. Penyusunan Laporan Keuangan Bagi Pondok Pesantren .

2. Contoh Penggunaan Aplikasi Teknologi Laporan Keuangan.

3. Menganalisa Laporan Keuangan Pondok Pesantren.

4. Pengoptimalan Value Laporan Keuangan Pondok Pesantren Bagi Peningkatan Kesejahteraan Pondok.

Laporan keuangan dalah gambaran kondisi keuangan sebuah entitas yang dibuat dengan tujuan untuk memberikan informasi keuangan entitas tersebut dan digunakan sebagai bentuk pertanggung jawaban kepada pemangku kepentingan. Laporan keuangan pesantren seharusnya disusun berdasarkan Pedoman Akuntansi Pesantren yang telah ditetapkan oleh BI bersama IAI dibuat sebagai pedoman bagi pesantren untuk melakukan pelaporan keuangan sebagai bentuk pertanggung jawaban atas amanah yang diterima dan dikelola. (Bashori, 2018). Tujuan laporan keuangan yang disusun dan disajikan oleh yayasan pondok pesantren adalah: Memberikan informasi tentang posisi keuangan, kinerja, arus kas dan informasi lainnya yang bermanfaat bagi penggunalaporan keuangan dalam rangka membuat keputusan ekonomi; dan sebagai bentuk pertanggungjawaban pengurus yayasan pondok pesantren atas penggunaan sumber daya yang dipercayakan kepadanya. Pengurus yayasan pondok pesantren bertanggung jawab atas penyusunan dan penyajian laporan keuangan.

Pedoman Akuntansi Pesantren yang diterbitkan Ikatan Akuntan Indonesia (IAI) dan Bank Indonesia (BI) merupakan salah satu contoh keberpihakan instansi yang konsern terhadap perkembangan akuntansi untuk pesantren.(Yanuar, 2018). Laporan keuangan yang lengkap berdasarkan Pedoman Akuntansi Pesantren dari yayasan pondok pesantren terdiri atas: Laporan Aktivitas, Laporan Arus Kas, Laporan Posisi Keuangan dan Catatan Atas Laporan Keuangan.

Laporan keuangan yayasan pondok pesantren disusun dalam Bahasa Indonesia. Mata uang fungsional dan pelaporan dari laporan keuangan yayasan pondok pesantren adalah rupiah. Yayasan pondok pesantren mencatat dan melaporkan setiap transaksi yang terjadi di yayasan pondok pesantren menggunakan mata uang rupiah. Transaksi yayasan pondok pesantren yang menggunakan mata uang selain rupiah dibukukan dengan menggunakan kurs transaksi. Saldo aset dan liabilitas dalam mata uang asing dijabarkan ke dalam rupiah menggunakan kurs tengah Bank Indonesia pada tanggal pelaporan (IAI, 2015)

Kebijakan akuntansi yayasan pondok pesantren harus mencerminkan prinsip kehati-hatian dan mencakup semua hal yang material serta sesuai dengan ketentuan dalam SAK ETAP. Pedoman Akuntensi Pesantren (PAP) disusun berdasarkan acuan SAK ETAP yaitu Standar Akuntansi Keuangan Entitas Tanpa Akuntabilitas Publik serta menggunakan PSAK no 45 tentang organisasi nirlaba serta ISAK syariah (Yanuar, 2018). Dalam hal SAK ETAP belum mengatur secara spesifik masalah pengakuan, pengukuran, penyajian atau pengungkapan dari suatu transaksi atau peristiwa, maka pengurus yayasan pondok. Pesantren harus menetapkan kebijakan untuk memastikan bahwa laporan keuangan menyajikan informasi yang:

a. Relevan terhadap kebutuhan pengguna laporan keuangan untuk pengambilan keputusan; 
b. Dapat diandalkan, dengan pengertian menyajikan secara jujur posisi keuangan, kinerja keuangan, dan arus kas dari yayasan pondok pesantren; menggambarkan substansi ekonomi dari suatu kejadian atau transaksi dan tidak semata-mata bentuk hukumnya;

- Netral, yaitu bebas dari keberpihakan;

- Mencerminkan kehati-hatian; dan

- Mencakup semua hal yang material.

Dalam menetapkan kebijakan akuntansi tersebut, maka harus mempertimbangkan:

a. Persyaratan dan panduan dalam SAK ETAP yang berhubungan dengan hal yang serupa;

b. Definisi, kriteria pengakuan dan konsep pengukuran aset, liabilitas, pendapatan, dan beban dalam Konsep dan PrinsipPervasif dari SAK ETAP;

c. Persyaratan dan panduan dalam SAK yang berhubungan dengan isu serupa dan terkait.

Konsistensi Penyajian Laporan keuangan menyajikan secara wajar posisi keuangan, kinerja keuangan, dan arus kas dari yayasan pondok pesantren, disertai pengungkapan yang diharuskan sesuai dengan ketentuan yang berlaku. Laporan posisi keuangan memberikan informasi mengenai aset, liabilitas, dan aset neto dari yayasan pondok pesantren, serta hubungan antar unsur-unsur tersebut pada waktu tertentu. Aset disajikan berdasarkan karakteristiknya dan dikelompokan menjadi aset lancar dan aset tidak lancer. Liabilitas disajikan menurut urutan jatuh temponya dan dikelompokan menjadi liabilitas jangka pendek dan liabilitas jangka panjang. Aset neto disajikan menjadi aset neto tidak terikat, aset neto terikat temporer, dan aset neto terikat permanen.

Laporan aktivitas memberikan informasi mengenai kinerja keuangan yayasan pondok pesantren selama suatu periode laporan tertentu. Laporan aktivitas menyediakan informasi mengenai pengaruh transaksi dan peristiwa lain yang mengubah jumlah dan sifat aset neto, hubungan antar transaksi dan peristiwa lain, dan bagaimana penggunaan sumber daya dalam pelaksanaan berbagai program atau jasa.

Laporan arus kas memberikan informasi mengenai penerimaan dan pengeluaran kas dari yayasan pondok pesantren selama periode laporan tertentu. Kas dan setara kas diklasifikasikan menjadi arus kas dari operasi, investasi, dan pendanaan. Arus kas dari operasi disajikan dengan metode tidak langsung.

Catatan atas laporan keuangan harus disajikan secara sistematis dengan urutan penyajian sesuai komponen utama laporan keuangan yang merupakan bagian yang tidak terpisahkan dari laporan keuangan. Informasi dalam catatan atas laporan keuangan berkaitan dengan pos-pos dalam laporan posisi keuangan, laporan aktivitas, dan laporan arus kas yang sifatnya memberikan penjelasan, baik yang bersifat kualitatif maupun kuantitatif.

Materialitas dalam penyajian laporan keuangan yayasan pondok pesantren didasarkan pada konsep materialitas. Pos-pos yang jumlahnya material disajikan tersendiri dalam laporan keuangan, sedangkan yang jumlahnya tidak material dapat digabungkan sepanjang memiliki sifat atau fungsi yang sejenis. Informasi dianggap material jika kelalaian untuk mencantumkan, atau kesalahan dalam mencatat, informasi tersebut dapat mempengaruhi keputusan yang diambil.

Periode Pelaporan Laporan keuangan yayasan pondok pesantren disajikan secara tahunan berdasarkan tahun hijriah atau masehi. Dalam hal yayasan pondok pesantren baru berdiri, maka laporan keuangan dapat disajikan untuk periode yang lebih pendek dari satu tahun. Dengan memiliki laporan keuangan yang sesuai standar, maka para stakeholder dapat melihat kondisi aset,liabilitas, maupun aset neto yang dimiliki oleh pondok pesantren (Syarifuddin, 2020). Sebagai lembaga pemegang amanah, pondok pesantren wajib untuk mencatat setiap transaksi dalam bentuk laporan keuangan untuk kegiatan operasionalnya. Kemudian melaporkan kepada para donatur dan pihak terkait secara transparan dan akuntabel sesuai dengan Pedoman Akuntansi Pesantren tentang pelaporan keuangan pondok pesantren.(Santi, 2019).

\section{KESIMPULAN DAN SARAN}

Kesimpulan dari hasil pengabdian yang dilaksanakan secara keseluruhan terjadi kenaikan pengetahuan dan pemahaman peserta pelatihan rata-rata 30 persen dari keseluruhan peserta. Sedangkan kenaikan sebesar 0 persen dialami oleh 5 peserta yang tetap belum memahami mengenai materi yang 
disampaikan dan merasa kurang cukup waktunya, membutuhkan penjelasan secara lebih intensif. 100 persen peserta kegiatan rata-rata belum pernah mengikuti pelatihan sejenis, sehingga dibutuhkan pendampingan lebih lanjut.

\section{Ucapan terima kasih}

Pada kesempatan ini Tim Pengabdian mengucapan terima kasih pada LPPM Universitas Lampung dan Pengelola Pondok Pesantren Al Hidayah dan Pondok Pesantren Darul Iman.

\section{REFERENSI}

Afkarina, I. A. (2019). Rekonstruksi Penyusunan Laporan Keuangan di Pondok Pesantren Al-Anwari Banyuwangi (dalam Perspektif Pedoman Akuntansi Pesantren). repository.unej.ac.id. Retrieved from https://repository.unej.ac.id/handle/123456789/90569

Alfani, M. L. (2016). Analisis implementasi Sistem Informasi Akuntansi Pada Koperasi Pondok Pesantren Al-Amin Mojokerto. etheses.uin-malang.ac.id. Retrieved from http://etheses.uinmalang.ac.id/id/eprint/10480

Auliavirda, R. (2019). Penerapan pedoman akuntansi pesantren dalam penyusunan laporan keuangan Pondok Pesantren Salaf Al-Qur'an (PPSQ) Asy-Syadzili Malang. etheses.uin-malang.ac.id. Retrieved from http://etheses.uin-malang.ac.id/id/eprint/16324

Bashori, M. A. (2018). Buku Pedoman Akuntansi Pesantren. Diperoleh tanggal.

Firmansyah, I. A. (2019). Analisis Penerapan Laporan Keuangan Berdasarkan Pedoman Akuntansi Pesantren Pada Pondok Pesantren Al-Qur'an Zaenuddin .... repository.upstegal.ac.id. Retrieved from http://repository.upstegal.ac.id/436/

Huda, M. (2019). Analisis penerapan akuntansi pesantren di Pondok Pesantren Tahfidzul Qur'an dan Pendidikan Da'i Al Uswah Tuban. etheses.uin-malang.ac.id. Retrieved from http://etheses.uinmalang.ac.id/id/eprint/16489

IAI. (2015). Pedoman Akuntansi Pesantren: Efekti per Mei 2018. Jakarta: Departemen Ekonomi ....

Lulita, T. N. (2019). Implementasi akuntansi pesantren pada pondok pesantren putri Al-Lathifiyyah 1 Bahrul Ulum Tambakberas Jombang. etheses.uin-malang.ac.id. Retrieved from http://etheses.uinmalang.ac.id/id/eprint/15102

Niati, A., Suhardjo, Y., Wijayanti, R., \& ... (2019). Pelatihan Pengelolaan Manajemen Keuangan dan Pelaporan Keuangan Akuntansi Pesantren bagi Pengelola Yayasan Pondok Pesantren X di Kota Semarang. Jurnal Surya .... Retrieved from http://103.97.100.145/index.php/JSM/article/view/4581

Santi, N. (2019). Analisis Pelaporan Keuangan Yayasan Pondok Pesantren Berdasarkan Pedoman Akuntansi Pesantren (Studi Pada Az Zahra Islamic. repository.radenintan.ac.id. Retrieved from http://repository.radenintan.ac.id/9227/1/PUSAT.pdf

Suherman, L. P. (2019). ANALISIS PENERAPAN AKUNTANSI PESANTREN PADA PONDOK PESANTREN DI SUKABUMI (Studi Kasus Di Pondok Pesantren Al-Ma'tuq Sukabumi). eprints.ummi.ac.id. Retrieved from http://eprints.ummi.ac.id/1443/

Sulistiani, D. (2020). Akuntansi Pesantren Sesuai SAK ETAP dan PSAK 45 Dalam Penyusunan Laporan Keuangan. AKTSAR: Jurnal Akuntansi Syariah. Retrieved from http://journal.iainkudus.ac.id/index.php/aktsar/article/view/7198 
Susetyo, S. H. B., Atikah, S., \& Fitriyah, N. (2020). Pelatihan Akuntansi Aset Tetap Di Pondok Pesantren 'NH'Kabupaten Lombok Barat. Jurnal PEPADU. Retrieved from http://jurnal.lppm.unram.ac.id/index.php/jurnalpepadu/article/view/72

Syarifuddin, L. (2020). Penyusunan laporan keuangan berdasarkan pedoman akuntansi pesantren pada Pondok Pesantren Anwarul Huda Kota Malang. etheses.uin-malang.ac.id. Retrieved from http://etheses.uin-malang.ac.id/id/eprint/18066

Yanuar, F. (2018). Kajian Literatur Implementasi Pedoman Akuntansi Pesantren (PAP). An-Nawa: Jurnal Studi Islam. Retrieved from http://jurnal.staiannawawi.com/index.php/annawa/article/view/127 